Ya. B. Nemyrovskyi ${ }^{1}$, Dr. Sc. (Tech.), orcid.org/0000-0001-8005-8584, V.V. Krivosheya ${ }^{2}$, Cand. Sc. (Tech.), orcid.org/0000-0002-0578-7485, S. E. Sardak ${ }^{3}$, Dr. Sc. (Econ.), Assoc. Prof., orcid.org/0000-0002-4716-3355, I. V. Shepelenko ${ }^{1}$, Cand. Sc. (Tech.), Assoc. Prof., orcid.org/0000-0003-1251-1687, Yu. A. Tsekhanov ${ }^{4}$, Dr. Sc. (Tech.), Prof., orcid.org/0000-0003-1315-8491
1 - Central Ukrainian National Technical University, Kropyvnytskyi, Ukraine, e-mail: provotorova1951@gmail.com 2 - V. Bakul Institute for Superhard Materials, Kyiv, Ukraine 3 - Oles Honchar Dnipro National University, Dnipro, Ukraine, e-mail: dnus@ukr.net

4 - Voronezh State Technical University, Voronezh, Russian Federation

\title{
THE USE OF DEFORMING BROACHING FOR ENHANCING THE EFFICIENCY OF CUTTER CHISELS
}

Purpose. To determine the potential of deforming broaching for the improvement of efficiency of cutter chisels in the mining industry.

Methodology. The study of the application of the technological process of deforming broaching was carried out based on the experimental research into conditions of assembly of press couplings corresponding to cutting rock-destroying tools, the working surface of which is reinforced with solid-alloy inserts.

Findings. Based on the conducted research, a new process of assembling the crowns of cutter chisels with the use of deforming broaching was developed.

Originality. It was determined that the range of angles of inclination of generatrix of the working cone of the deforming element and the roll-treading lip of the insert, which are necessary for efficient machining and pressing in crowns of cutters, is $4-16^{\circ}$. It was proven that the "solid alloy-steel" press couplings for cutter chisels will have the maximum bearing capacity at total tension $a / d_{0} \leq 3 \%$. It was found that it is necessary to foresee the following distribution of tensions: to perform $2 \%$ of deformation by preliminary deforming broaching, and $1 \%$ - by pressing in an insert

Practical value. The use of deforming broaching makes it possible to increase the strength of fastening the inserts of cutter chisels by 2 times, to reduce specific consumption of the tool by 4.4 times, and to increase the average drilling rate by 4 times.

Keywords: deforming broaching, press coupling, crown of cutter chisel, tension

Introduction. The process of deforming broaching is used: for machining deep bores in tubular work pieces and cylindrical nodes; in restoring dimensional accuracy and machining piston pins and cross-pointing hinges; diamond drilling extenders, casings of break cylinders and hydrocylinders and so on. The positive technical-economic properties of the deforming broaching process make its further spread in mining, coal, gas, metallurgical and machine building industries expedient [1].

This study deals with the technological aspects of the process of applying deforming broaching to enhance the efficiency of cutter chisels. Improvement of the existing and creation of the new methods for machining the working surfaces of a chisel is an urgent task of modern scientific research focusing on studying the kinematics of drilling chisels, interaction of the elements of the cutting structure of a drilling chisel with destroyed rock, calculation of forces and analysis of tension of bearing drilling chisels and the elements of a cutting structure, review of the experimental methods and the methods of mathematical modeling, as confirmed by the publications of A.I.Afanasiev, D. I. Simisinov, V. S. Shestakov [2], A. Hosseini, H. A. Kishawy, B. Moetakef-Imani [3], V.V. Krivosheja [4], S. F. Studenets, P.M. Yeromin, O. V. Chernyavsky [5], V.A. Pyalchenkov, L. I. Nikitina [6], V.A. Pyalchenkov, V. V. Dolgushin, G.A. Kulyabin [7], S. E. Sheikin, I. Yu. Rostotsky [8], A. F. Salenko, A. N. Fedotiev, L.P. Fedotieva, A.M. Mana [9], F.Zanger, N. Boev, V. Schulze [10].

The authors note that one of the main working nodes of cutting rock-destroying tools is crowns, reinforced with solidalloy inserts. The crowns (Fig. 1) are usually made of thermally treated steels $35 \mathrm{HGSA}$ or $20 \mathrm{H} 2 \mathrm{~N} 4 \mathrm{~A}$, and inserts - from solid alloy VK15.

The assembly of cutter crowns is usually performed by pressing in the insert into the crown bore. This method is the

(C) Nemyrovskyi Ya. B., Krivosheya V.V., Sardak S. E., Shepelenko I. V., Tsekhanov Yu. A., 2020 simplest and is characterized by high-performance, although it has some drawbacks. They include the following. In assembly, especially with large tensions, partial destruction of contact surfaces is possible, which reduces the strength of the press coupling. This is especially common at considerable hardness of the material of a crown (HRC 57-60), when its material becomes brittle as a result of heat treatment. Therefore, the hardness of the crown is usually limited to the value of HRC of 42, and to increase its durability, it is recommended to cement the outer surface of the crown.

The conditions of pressing in have a significant impact on the performance of the rock-destroying tool. In the process of operation, the crown of a cutter chisel is under the influence of significant dynamic loads, which occur during the destruction of rocks. One of the main reasons for the failure of a tool is the fallout of solid-alloy inserts from the crown of the cutter due to the lack of reliability of the press coupling

The well-known technological process of machining the bores in the crowns of cutters includes low-performance drilling, sender and reaming operations. These operations do not always ensure the necessary quality of the surface of the treated bore, which, naturally, negatively affects the reliability of the press coupling.

One of the effective ways to increase the strength of press coupling is the use of the methods of cold plastic deformation, in particular, deforming broaching or perforation (DB). For all the variety of research into the application of the DB, the problem of using this process in the technology of machining the bores in the crowns of cutters has not been explored. In this regard, there is a need for special studies on the feasibility of using the DB in machining the bores in cutter crowns.

Thus, the task of the research in this work is to improve the reliability of the press coupling of a solid-alloy insert - the crown of the cutter casing - due to the use of the process of $\mathrm{DB}$, which will make it possible to improve the quality of the surface layer of the machined bore, and therefore, the process 


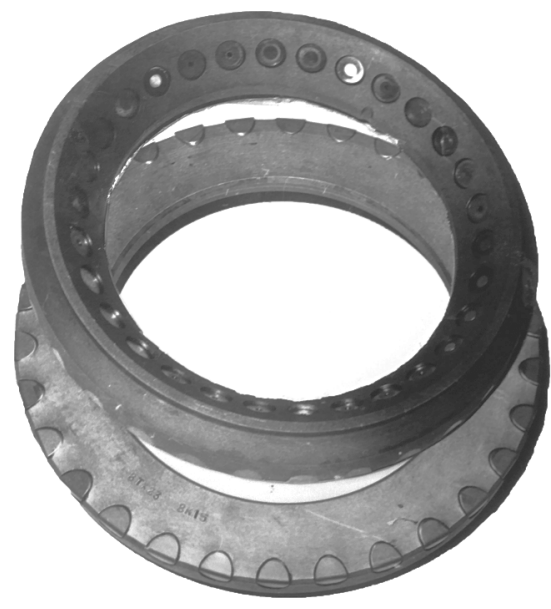

Fig. 1. The crown of a cutter in assembly

of assembling the crowns of cutter chisels, which in turn will enhance the efficiency of the rock-destroying tool

Methods. In order to develop the new technological process, the authors carried out experimental studies on the conditions of assembly of press couplings, corresponding to cutting rock-destructive tools, the working surface of which is reinforced with solid-alloy inserts.

Steels $35 \mathrm{HGSA}$ and $20 \mathrm{H} 2 \mathrm{~N} 4 \mathrm{~A}$ were used as the material for the experimental work pieces, and the inserts were made of solid alloy VK15. The diameters and length of the press coupling were selected equal to the diameter and depth of the bore in the cutter crowns and were equal to 12 and $20 \mathrm{~mm}$, respectively. The bores in the steel samples were made as through and step. The bore machining was performed by perforation (Fig. 2), the working part 1 of which was made of solid alloy VK15, and the casing 2 was made of thermally treated steel 30HGSA of the hardness of $38 \ldots 42$ HRC. The casing has a cylindrical part 3 for mounting the tool in the executive part of the press. To measure the forces during pressing in and pressing off, as well as at direct and reverse strokes of the tool, a tensometric dynamometer of the known design was used [4].

The parameters of roughness of the surface layer were measured by the profilographer-profilometer VEI "Caliber" of model 201. If necessary, the measurement of the support length of the profile was made by an electronic set-top box to the profilographer-profilometer VEI "Caliber" of model 201, which works in the profilometric mode. In accordance with the GOST (State standard) 10356-78, deviations of the treated bores were measured by the inside caliper with the measuring head (scale division is $0.01 \mathrm{~mm}$ ).

Results. At the beginning of the study, the effect of wall thickness on the strength of the press couplings was studied. Existing cutter designs have the pitch of inserts equal to $1.7 \mathrm{~d}$ (where $d$ is the diameter of the insert), that is, the thickness of the jumper between the bores is 0.7 of diameter of the insert. At the same time, as the thickness of the wall increases, the force of the pressing out increases, and only when the wall thickness $t_{0}$ reaches the value of $d$, its influence on the force of pressing out stops (Fig. 3).

This is consistent with the known pattern, determined in deforming broaching of work pieces with an infinite thickness of the wall, that is, when the wall thickness is equal to or larger

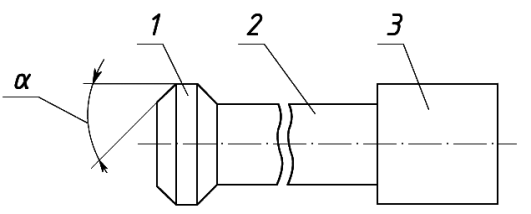

Fig. 2. Deforming perforation for machining of dead-end bores

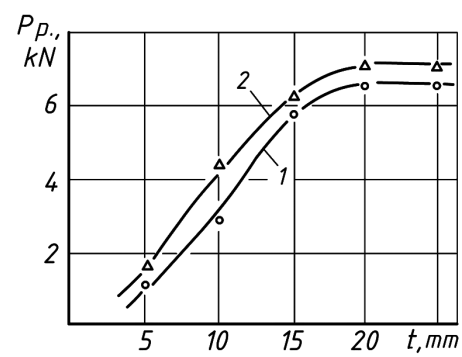

Fig. 3. Dependence of pressing out force on wall thickness, the diameter of conjugation - $20 \mathrm{~mm}$, the material: of the casing is steel 20H2N4A, of the insert - solid alloy VK15:

1 - without pre-deformation; 2 - with pre-deformation $a_{d}=$ $=0.03 \mathrm{~mm}$

than the diameter of the bore. In this case, there is no plastic deformation of the outer surface. Therefore, taking into account the experiments shown in Fig. 3, it is necessary to increase the pitch of the inserts from $1.7 d$ to $2 d$. The studies conducted in testing such a tool under working conditions show that such a change in the pitch between the inserts did not have a significant impact on the effectiveness of rock destruction.

In addition, the pre-deformation of the bore also increases the force of pressing out (curve 2, Fig. 3), which indicates the prospect of using the operation of deforming broaching for machining the bores before pressing in.

Thus, the conducted experiments showed the need to increase the pitch of inserts in the cutter crown up to $2 d$ and to carry out additional studies on the choice of broaching modes and the geometry of the tool for the preliminary operation of deforming broaching and subsequent pressing in.

The studies were carried out on the samples with an infinite wall thickness, made of 35HGSA steel. Based on the experiments and preliminary calculations, the range of the angles of inclination of the generatrix of the working cone $\alpha$ of the deforming element and the roll-threading lip of an insert required for successful machining and pressing in, which is 4-16 $6^{\circ}$, was determined.

Moreover, the performed experiments and calculations showed that the values of these angles in the specified range have little or no effect on the strength of the press coupling. This is because during machining the work pieces with an infinite thickness of the wall, the properties of the surface of the surface layer, namely, reinforcement, roughness, almost do not depend on angle $\alpha$. The dimensions of the treated bore do not depend on angle $\alpha$ either (shrinkage after deforming with different angles is virtually the same).

The choice of the specified range of angles is caused by the following reasons. Using angles $\alpha<4^{\circ}$ leads to difficulty in machining at deforming broaching of dead-end bores due to increasing the height of the working cone of the insert. When pressed, an increase in the length of the roll-treading lip of an insert reduces the area of contact of the cylindrical part of the insert stem, which in turn reduces the strength of its fastening in the crown.

The use of angle $\alpha>16^{\circ}$ in the deforming tool can cause the partial cutting of the inner surface of the bore by the cutting edge, formed at the place of conjugation of the working cone and the cylindrical strip. A similar pattern takes place during pressing the insert into the crown bore. The cutting edge, formed at the place of intersection of conical and cylindrical parts of the insert during pressing in, even with a slight skew, begins to cut the surface of the bore. This leads to an increase in the skew of the insert and a sharp decrease in the strength of its fastening in the cutter crown.

Consider the effect of tension on the element and the total tension on the strength of the press coupling. To do this, the solid-alloy insert was pressed in with various tension, in this case, some samples before pressing were machined by a de- 
forming element. Fig. 4 shows the dependence of specific force of the pressing out (the ratio of pressing out to the area of the matched surface of coupling) on pressing in tension. Curve 1 corresponds to forces of pressing out the inserts that were pressed in after drilling. Curve 2 corresponds to the forces of pressing out of the inserts pressed in the bore after pre-deformation by the working element with tension of $0.1 \mathrm{~mm}$; curve 3 - after pre-treatment with $0.2 \mathrm{~mm}$ tension. As Fig. 4 indicates, in all cases, the force of pressing out increases linearly with an increase in tension, reaching a certain maximum at $P \approx 80 \mathrm{MPa}$, and then decreases. At a further increase in pressing in tension, the force of pressing out somewhat increases, but it does not exceed the previously achieved value of maximal force of pressing out.

Analysis of curves 2 and 3 (Fig. 4) shows that the maximum force of pressing out is achieved at lower values of pressing in tension. If we construct the dependence of pressing out force on total tension (tension of pre-deformation and tension of pressing in), all the values of the pressing in force can be characterized by one curve $P_{\text {s.p. }}=f\left(\sum a\right)$. The nature of this curve corresponds to the nature of curves 1, 2, 3 (Fig. 4).

This indicates that tension of pre-deformation and tension of pressing in represent a single process of plastic deformation of the inner surface of a bore. This pattern of a change in the force of pressing out is explained by the significant reinforcement of the machined surface. The hardness of the surface layer increased by 1.3-1.4 times, and the drop in pressing out force - by some exhaustion of the resource of plasticity of the bore surface at total tension $\sum a>0.4 \mathrm{~mm}$.

Experiments show that during the DB, there occurs deformational reinforcement of the surface layer, in this case its hardness increases, which ensures the reliability of fastening the inserts in the casing. Take a closer look at the mechanics of reinforcement of the surface layer during the DB. As shown above, the force of pressing out after the DB does not depend on the angle, the number of passes and the tension on the deforming element. Therefore, in order to improve productivity, it is advisable to implement the DB in one pass. However, to obtain high hardness of the surface layer of the crown bore, it is possible either to change the angle or carry out multi-cycle treatment.

For work pieces with an infinite wall thickness, the distribution of intensity of plastic deformations in surface layer $\overline{\mathrm{e}}_{0}$ after the DB is presented in Fig. 5. In it, $\bar{e}_{0 i}$ is marked on axis $y$, and $h / \delta$ is marked on axis $x$, where $h$ is the thickness of the reinforced layer, $\delta$ is the tension on the side (i. e., exceeding of the radius of the deforming element the original radius of the bore). In multi-cycle machining, the total accumulated deformation is determined by the superposition principle, by summing up its increments for $N$ cycles of the DB

$$
e_{i}=\sum_{1}^{N} \Delta e_{i},
$$

where $N$ is the number of deformation cycles.

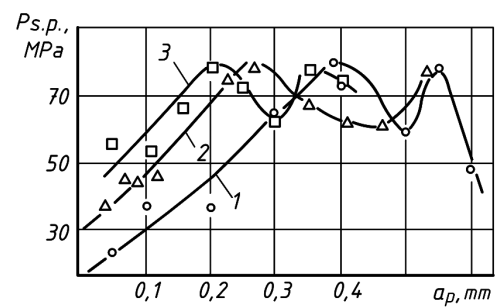

Fig. 4. Dependence of specific force of pressing out on tension of pressing in, the diameter of conjugation is $12 \mathrm{~mm}$, the material of the casing is steel 35HGSA, of inserts - solid alloy VK15:

1 - without pre-deformation; 2 - pre-deformation $a_{d}=0.1 \mathrm{~mm}$; $3-a_{d}=0.2 \mathrm{~mm}$

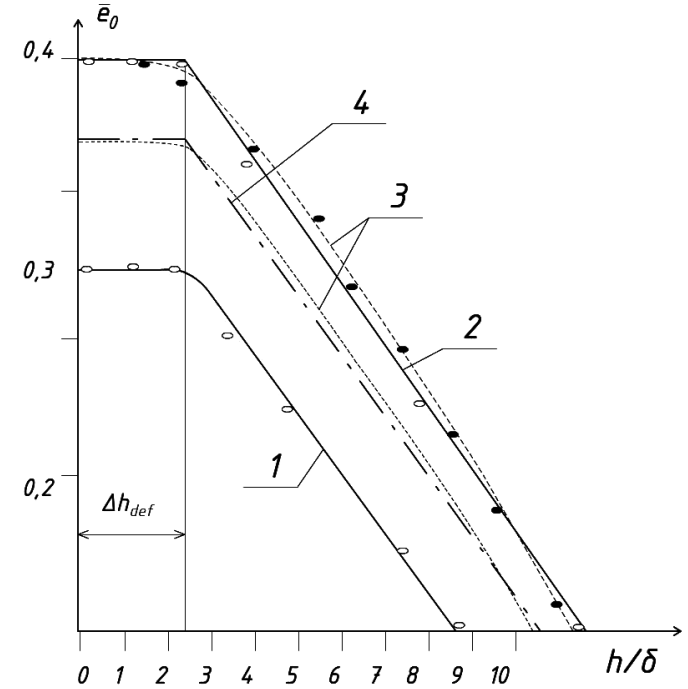

Fig. 5. Universal dependences $\bar{e}_{0}$ on relative depth of the surface layer of the workpiece $h / \delta$ :

1 -for the parts treated by the tool with the inclination angle of the generatrix $\alpha=5^{\circ} ; 2-$ for the parts, treated by the tool with $\alpha=10^{\circ}$; 3 - the curves obtained by the method for measuring micro-hardness; 4 - the curve obtained by the interpolation of curves 1 and 2 for treatment by the tool with the angle of inclination of the generatrix $\alpha=8^{\circ} ;$ Distribution $\bar{e}_{0}$, obtained by the method for measuring the hardness, is shown by the dotted line

It is possible to determine the magnitude of hardness with the help of the calibration chart, linking $e_{i}$ to hardness $H V$.

If according to the technical conditions, $\mathrm{HV}$ is assigned for the part, it can be obtained by selecting the following technological parameters: angle $\alpha$, tension on element $a$ and $N$. There is the relation between $\sigma_{i}$ and $H V$

$$
\sigma_{i}=0.33 H V \text {. }
$$

Value $\sigma_{i}^{*}$ is connected with the reinforcement curve

$$
\sigma_{i}^{*}=\sigma_{i}\left(e_{i}\right)
$$

Therefore, knowing $e_{i}$, we determine $\sigma_{i}^{*}$ with the help of (3); magnitude $H V$ is determined with consideration of (2).

Consider the example of such technological calculation for the case of the DB, when machining was performed by an element with angle $\alpha=8^{\circ}$ per pass, i.e. $N=1$. The reinforcement curve for steel 35HGSA is shown in Fig. 6.

We find $\Delta e_{i}=0.34$ from the diagram (Fig. 5) of interpolation for angle $\alpha=8^{\circ}$. From Fig. 6 we find $\sigma_{i}=1000 \mathrm{MPa}$. Then from dependence (2), we obtain, GPa

$$
H V=\frac{\sigma_{i}}{0.33}=3030 \mathrm{MPa}=3.03 .
$$

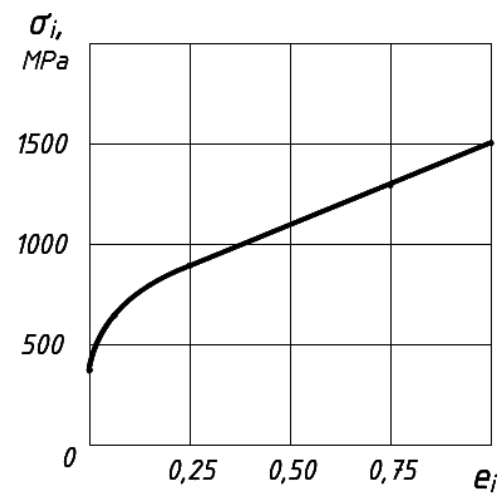

Fig. 6. Curve of reinforcement of steel $35 H G S A$ 
The experimental value of $H V$, shown in Table 1 , is equal to $3.1-3.2 \mathrm{GPa}$, the calculation error is approximately $4 \%$.

If, for example, in this case the expansion of the bore is performed by two passes, $e_{i}=2 \Delta e_{i}=0.68$, and $\sigma_{i}=1250 \mathrm{MPa}$, $H V=3800 \mathrm{MPa}=3.8 \mathrm{GPa}$. That is, due to the multiplicity of deformation, hardness can be additionally increased by $25 \%$.

It should be noted that further increase in hardness due to deformation reinforcement leads to the material becoming brittle and micro defects accumulating in it, which negatively affects the strength of the press coupling under conditions of variable loads:

In our experiments, we considered the force of pressing out of rest, that is, at the moment prior to the onset of relative displacement of conjugated surfaces. For our coupling, the solidalloy insert - a steel crown of a cutter, working under conditions of large dynamic loads, an important indicator of its performance is specific force of pressing out in the process of the set relative displacement of the conjugated parts. That is, it is necessary to know how specific friction forces between conjugated surfaces will change after their relative displacement. Therefore, we additionally examined the oscillograms of recording the force at pressing out a solid-alloy insert. For example, consider oscillograms (Fig. 7). As it follows from Fig. 7, $a$, after the displacement of the insert, the force of pressing out decreases inconsiderably and the tool continues to be capable of working. At the same time, the oscillogram (Fig. 7, $b$ ) shows that when the total tension of assembly $\sum a>0.4 \mathrm{~mm}$ increases, the pressurization force drops sharply and the tool becomes incapable of working, that is the total tension of machining and pressing in should not exceed $\sum a<0.4 \mathrm{~mm}$.

Dependence $P_{\text {s.p. }}=f\left(\sum a\right)$ was constructed according to the data in the oscillograms during pressing out (Fig. 8). It is similar to the curve (Fig. 3), has an extreme character, and the maximums of force coincide. Despite the fact that the force of pressing out of rest after its decrease increases slightly, the force of pressing in at the set relative displacement always monotonously decrease.

Therefore, the press couplings, solid alloy - steel for cutting chisels will have the maximum bearing capacity at total tension $a / d_{0} \leq 3 \%$. Taking into account that at a decrease in the tension of pressing in, its conditions improve, it is necessary to carry out $2 \%$ of deformation by preliminary deforming broaching, and $1 \%$ - during pressing in the insert. This distribution of tensions increases the efficiency of cutter chisels.

Consider how the operation of deforming broaching affects the accuracy of the treated bores. The errors of the treated bore play an important role in the assembly of the crown.
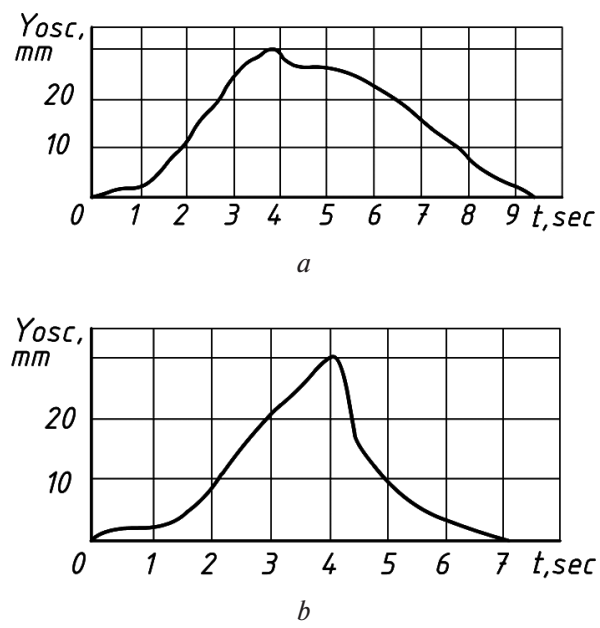

Fig. 7. Oscillograms of recording the force during pressing out solid-alloy inserts, pressed in with the $0.1 \mathrm{~mm}$ tension into the bore, pre-treated with tension:

$a-0.1 \mathrm{~mm} ; b-0.4 \mathrm{~mm}$

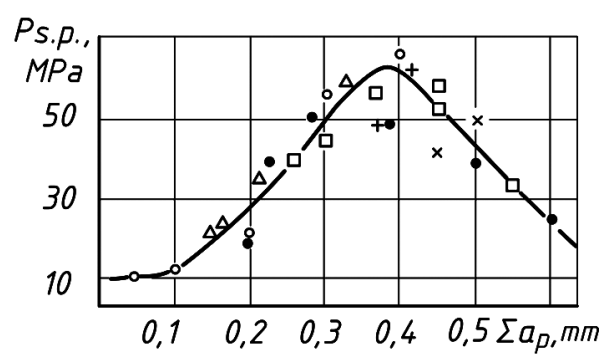

Fig. 8. Dependence of specific force of pressing out on total tension at the set relative displacement of conjugated parts, the diameter of conjugation - $12 \mathrm{~mm}$, material of the casing steel 35HGSA, of the insert - solid alloy VK15:

- - without preliminary deformation, preliminary deformation with tension: $\Delta-a_{d}=0.1 \mathrm{~mm}, \bullet-a_{d}=0.15 \mathrm{~mm}, \square-a_{d}=0.2 \mathrm{~mm}$, $+-a_{d}=0.25 \mathrm{~mm}, \boldsymbol{\nabla}-a_{d}=0.3 \mathrm{~mm}, \times-a_{d}=0.4 \mathrm{~mm}$

They determine the tension of pressing in, and, therefore, performance of the entire tool. That is why, the studies on determining the deviations of bores in the cutter crowns after drilling and subsequent deforming broaching were carried out.

Drilling bores in the cutter crowns was carried out on a vertical-drilling machine of model $2 \mathrm{~A} 150$ with the drills with special sharpening and drilling modes for steels of such a class. To enhance the drilling accuracy, the machine was equipped with a special device, the uniform distribution of bores on the cutter crown was provided by the division device. To eliminate the removal of the drill at the initial time of drilling each bore, a replaceable conductor sleeve was used, and drilling in the casings of cutters was performed not from the work surface of the crown, but from its inner side (Fig. 9).

Deforming perforation of bores and pressing solid-alloy inserts into them were performed on the press PMM-200 using this specified device, as well as the inner part of the crown. This greatly facilitated the orientation of the perforation when machining the bore and the insert at the moment pressing in started. In addition, the insert was pressed in using a conductive sleeve (Fig. 10), which also improved the orientation of the insert and eliminated its skew.

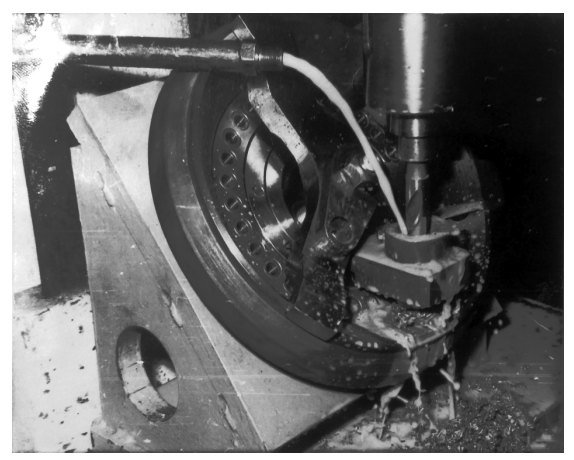

Fig. 9. Drilling bores in cutter crowns VT23

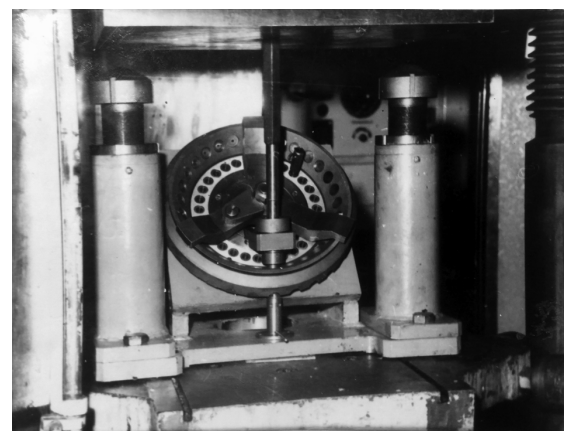

Fig. 10. Pressing solid-alloy inserts into cutter crowns VT23 
Fig. 11 shows the results of measuring a batch of bores in the crowns of cutters of steel 35HGSA after their drilling and deforming perforation. The results of the measurement of the drilled bores indicate the normal flow of the drilling process, which made it possible to obtain the bores of the 9-10 accuracy degree. Obtaining this accuracy after drilling allowed machining them with deforming perforation without additional machining of the bore by reaming. This significantly reduced the deviation of the bores (Fig. 11), which made it possible to ensure the 7 accuracy degree for them. To compare the effectiveness of the existing and proposed technical processes, the analysis of their parameters of the quality of machined surfaces (Table) was performed.

According to Table, the proposed technological process is much more efficient, and the indicators of the quality of the treated surface exceed those obtained in the treatment following the existing technological process. Thus, the supporting surface (percentage of metal in the rough layer) is almost twice as high, the value of $\mathrm{Ra}$ is much lower, the hardness of the surface after broaching is $30 \%$ higher than in the existing technological process, macro deviations of the surface of the bores made by the proposed technological process are much lower. All this taken together provides an increase in the strength of the press coupling due to the reinforcement of material, stable tension and improved indicators of the rough layer. The above is proved by the experimental data, which made it possible to compare the values of the specific forces of pressing off solidalloy inserts from steel bodies assembled: by mechanical pressing in after processing the holes by deployment; thermally, namely heating the housing and cooling the insert; as well as mechanical pressing in after processing the holes by deforming broaching.

The experiments showed that the smallest specific force of pressing out the inserts - $40 \mathrm{MPa}$ was observed when they were pressed after processing the holes by deployment, the pressing force of the inserts $60 \mathrm{MPa}$ was somewhat higher when the casings were assembled by the thermal method, and the most effective was the pressing in of the inserts into the case, the holes of which were previously processed by deforming pulling. In this case, the specific pressing in force reaches $80 \mathrm{MPa}$.

Therefore, of the three variants of assembling the crowns of cutter chisels, the most effective is the option implemented using the new technological process based on deforming broaching. The strength of fastening the insert in the cutter crown is almost twice as high. Even in comparison with the thermal method for fixing the inserts, the proposed technological process has an undeniable advantage; in particular, it provides the strength of fixing inserts, which is by 1.4-1.5 times higher at a significant decrease in labor-intensity for their fastening.

According to the developed technology, two batches of VT23 cutters having three pieces each and 2 batches of VP-23M cutters having 10 pieces each were made. Indus-
Indicators of the quality of machined surface after the existing and the proposed technological process

\begin{tabular}{|c|c|c|c|c|c|}
\hline \multirow{4}{*}{ 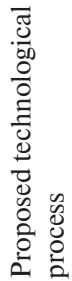 } & \multirow[b]{2}{*}{$\begin{array}{l}\text { Kind of } \\
\text { machining }\end{array}$} & \multicolumn{4}{|c|}{ Quality indicators } \\
\hline & & $\begin{array}{l}\mathrm{Ra}, \\
\mathrm{mm}\end{array}$ & $t_{m}, \%$ & $\begin{array}{l}\text { Hardness } \\
H V, \mathrm{GPa}\end{array}$ & $\begin{array}{c}\text { Deviation } \\
\text { of bores, } \\
\mathrm{mm}\end{array}$ \\
\hline & Drilling & $4-6$ & 36 & $2.45-2.5$ & +0.06 \\
\hline & Broaching & $0.3-0.8$ & 65 & $3.1-3.2$ & +0.02 \\
\hline 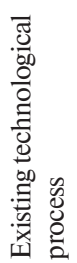 & $\begin{array}{l}\text { Drilling }+ \text { hole } \\
\text { enlarging }+ \text { reaming }\end{array}$ & $2-3$ & 39 & $2.45-2.5$ & +0.05 \\
\hline
\end{tabular}

trial tests of rock destroying crowns VP-23M on drilling machines of the "Strela" type were carried out at K. A. Rumyantsev mine of PA "Artemvuhillia". During the excavations, the average length of which was $6-8 \mathrm{~m}$, the following rocks intersected: sandstone with the strength of 7-12 units by the scale of M. M. Protodyakonov, sand slate with the strength of 5-7 and clay slate with the strength of up to 5 units. As a result of the tests, it was found that specific consumption of the tool is reduced compared to the serial one by 4.4 times, and the average drilling rate increased by 1.4 times. At the same time, the number of replacements of the treated crowns is by 4.4 times less than of the serial ones. The economic effect of the implementation of the developed technological process is largely determined by the durability of reinforced cutters and makes up $480000 \mathrm{UAH}$ per 100 cutters [1].

Conclusions. Based on the conducted research, a new technological process of assembling the crowns of cutter chisels with the use of deforming broaching was developed. The performed studies showed that pre-treatment by deforming broaching and pressing in the inserts is a unified process of plastic deformation of the surface of the bore. The quality indicators of the surface machined with the use of deforming broaching were examined. Comparative analysis of them with the quality indicators obtained according to the traditional technology showed the undoubted advantage of the new technological process. The conducted tests proved the prospects of using the new technological process of assembling cutter chisels due to reducing specific consumption of reinforced crowns compared to serial ones by 4 and 4.1 times. This will provide the expected economic effect of the operation of 100 cutters, which is $480000 \mathrm{UAH}$.

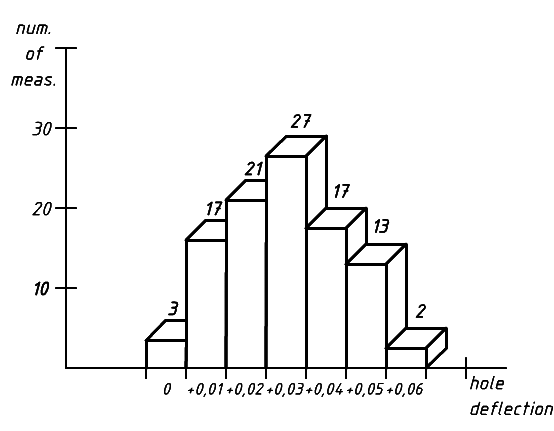

$a$

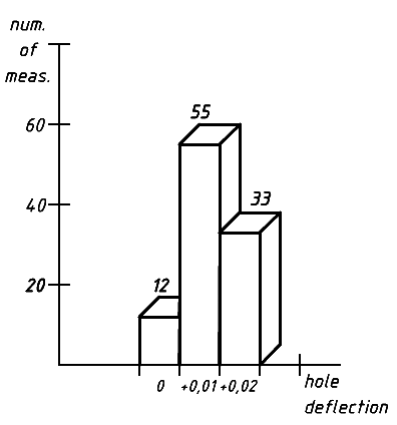

$b$

Fig. 11. Deviations of the machined bores:

$a$-after drilling; $b$ - after deforming broaching of a drilled bore 
References.

1. Nemyrovskyi, Ya., Posvyatenko, E., \& Sardak, S. (2019). Technical-Economic Aspects of the Use of Technological Process of Deforming Broaching. Advances in Design, Simulation and Manufacturing II. DSMIE 2019. Lecture Notes in Mechanical Engineering. Springer, Cham, 238-247. https://doi. org/10.1007/978-3-030-22365-6_24.

2. Afanasiev, A.I., Simisinov, D.I., \& Shestakov, V.S. (2014). Equivalent heat model of roller cone bit. Gornyi Zhurnal, 9, 52-56. 3. Hosseini, A., Kishawy, H. A., \& Moetakef-Imani, B. (2016). Effects of Broaching Operations on the Integrity of Machined Surface. Procedia CIRP, 45, 163-166. https://doi.org/10.1016/i. procir.2016.02.352.

4. Krivosheja, V. V. (2015). Effect of the deformation angle on the extension of cylindrical holes: monograph. Saarbrucken: LAP LAMBERT Academic Publishing.

5. Studenets, S. F., Yeriomin, P. M., \& Cherniavskyi, O. V. (2015). Influence of deformation conditions during the machining of hard-alloy combined broaches on the structure and hardening of the surface layer of cast irons. Superhard materials, 4, 91-99.

6. Pyalchenkov, V.A., \& Nikitina, L. I. (2017). Force measurement on lobes of rolling drilling bit (test procedure). ARPN Journal of Engineering and Applied Sciences, 12(17), 4990-4995. 7. Pyalchenkov, V.A., Dolgushin, V.V., \& Kulyabin, G.A. (2017). The model for studies of load for the roller bit support bearings. ARPN Journal of Engineering and Applied Sciences, 12(19), 5548-5553.

8. Sheikin, S. E., Pashchenko, E. A., Rostotsky, I. Yu., Gavrilova, V. S., \& Protsishin, V. T. (2014). Process lubricant for deforming drawing of pieces made of titanium. Metallurgy and Mining, 4, 38-43.

9. Salenko, A. F., Fedotiev, A. N., Fedotieva, L.P., \& Mana, A. M. (2015). Methods of obtaining and processing wear-resistant coatings for drill bits. Naukovyi Visnyk Natsionalnoho Hirnychoho Universytetu, (6), 48-54.

10. Zanger, F., Boev, N., \& Schulze, V. (2014). Surface quality after broaching with variable cutting thickness. Procedia CIRP, 13, 114-119. https://doi.org/10.1016/i.procir.2014.04.020.

\section{Застосування деформуючого протягування для підвищення працездатності шарошечних} доліт

\section{Я. Б. Немировський', В. В. Кривошея², С. Е. Сардак ${ }^{3}$, І. В. Шепеленко ${ }^{1}$ Ю. О. Цеханов ${ }^{4}$}

1 - Центральноукраїнський національний технічний університет, м. Кропивницький, Україна, e-mail: provotorova1951@gmail.com

2 - Інститут надтвердих матеріалів імені В.М.Бакуля, м. Київ, Україна

3 - Дніпровський національний університет імені Олеся Гончара, м. Дніпро, Україна, e-mail: dnus@ukr.net

4 - Воронезький державний технічний університет, м. Воронеж, Російська Федерація

Мета. Визначення потенціалу застосування деформуючого протягування для підвищення працездатності шарошечних доліт у гірничодобувній промисловості.

Методика. Дослідження застосування технологічного процесу деформуючого протягування здійснено на основі експериментального дослідження умов складання пресових з'єднань, шо відповідають шарошечним породоруйнуючим інструментам, робоча поверхня яких армована твердосплавними вставками.

Результати. На основі проведених досліджень розроблено новий технологічний процес складання вінців шарошечних доліт з використанням деформуючого протягування.

Наукова новизна. Визначено діапазон кутів нахилу утворюючого робочого конуса деформуючого елемента й забірного конуса вставки, необхідних для успішної обробки та запресовування вінців шарошок, що становить 4-16․ Доведено, що пресові з'єднання «твердий сплав сталь» для шарошечних доліт будуть володіти максимальною несучою здатністю при сумарному натягу $a / d_{0} \leq 3 \%$. Встановлено, що для підвищення працездатності шарошечних доліт необхідно передбачити наступний розподіл натягів: 2 \% деформації здійснювати попереднім деформуючим протягуванням, а $1 \%$ - при запресовуванні вставки.

Практична значимість. Застосування деформуючого протягування дозволяє підвищити міцність закріплення вставок шарошечних доліт у 2 рази, скоротити питомі витрати інструмента в 4,4 рази, а середню швидкість буріння збільшити в 1,4 рази.

Ключові слова: деформуюче протягування, пресове з'єднання, вінець шарошечного долота, натяг

\section{Применение деформирующего протягивания для повышения работоспособности шарошечных долот}

Я. Б. Немировский느, В. В. Кривошея ${ }^{2}$, С. Э. Сардак³, И. В. Шепеленко ${ }^{1}$ Ю. А. Цеханов

1 - Центральноукраинский национальный технический университет, г. Кропивницкий, Украина, e-mail: provotorova1951@gmail.com

2 - Институт сверхтвердых материалов имени В. М. Бакуля, г. Киев, Украина

3 - Днепровский национальный университет имени Олеся Гончара, г. Днепр, Украина, e-mail: dnus@ukr.net

4 - Воронежский государственный технический университет, г. Воронеж, Российская Федерация

Цель. Определение потенциала применения деформирующего протягивания для повышения работоспособности шарошечных долот в горнодобываюшей промышленности.

Методика. Исследование применения технологического процесса деформирующего протягивания осуществлено на основе экспериментального исследования условий сборки прессовых соединений, соответствующих шарошечным породоразрушающим инструментам, рабочая поверхность которых армирована твердосплавными вставками.

Результаты. На основании проведенных исследований разработан новый технологический процесс сборки венцов шарошечных долот с использованием деформирующего протягивания.

Научная новизна. Определен диапазон углов наклона образуюшей рабочего конуса деформирующего элемента и заборного конуса вставки, необходимых для успешной обработки и запрессовки венцов шарошек, составляющий 4-16 . Доказано, что прессовые соединения «твердый сплав - сталь» для шарошечных долот будут обладать максимальной несущей способностью при суммарном натяге $a / d_{0} \leq 3 \%$. Установлено, что для повышения работоспособности шарошечных долот необходимо предусмотреть следующее распределение натягов: 2 \% деформации осуществлять предварительным деформируюшим протягиванием, а $1 \%$ - при запрессовке вставки.

Практическая значимость. Применение деформирующего протягивания позволяет повысить прочность закрепления вставок шарошечных долот в 2 раза, сократить удельный расход инструмента в 4,4 раза, а среднюю скорость бурения увеличить в 1,4 раза.

Ключевые слова: деформирующее протягивание, прессовое соединение, венеи шарошечного долота, натяг

Recommended for publication by V.V.Aulin, Doctor of Technical Sciences. The manuscript was submitted 24.05.19. 